\title{
A prospective study to know the efficacy of short-term use of injectable depot medroxy progesterone acetate for contraception in tertiary care hospital from North West Rajasthan, India
}

\author{
Swati Kochar, Arun Kumar*, Ankur Nama, Neha Suthar
}

Department of Obstetrics and Gynecology, S. P. Medical College and A. G. H. Bikaner, Rajasthan, India

\author{
Received: 27 February 2020 \\ Revised: 01 April 2020 \\ Accepted: 09 April 2020 \\ *Correspondence: \\ Dr. Arun Kumar, \\ E-mail: drarunvijayeta@gmail.com
}

Copyright: () the author(s), publisher and licensee Medip Academy. This is an open-access article distributed under the terms of the Creative Commons Attribution Non-Commercial License, which permits unrestricted non-commercial use, distribution, and reproduction in any medium, provided the original work is properly cited.

\begin{abstract}
Background: Population explosion is a major issue especially in our country with the second largest population in world next only to china starting the use of contraception in postpartum period is an effective method of increasing the gap between two pregnancies and hence reducing the family size. Objective was to study the efficacy of DMPA injection in postpartum period for contraception.

Methods: The study was a prospective study conducted on 100 patients during June 2018 to May 2019 in the department of obstetrics and gynaecology, S. P. Medical College Associate A. G. H., Bikaner, Rajasthan, India.

Results: In present study mild irregular bleeding was present in 21, 35 and 38 cases at initial visit, at 3 months and at 6 months follow up respectively. Moderate irregular bleeding was present in 8 cases at initial visit, 27 cases at 3 months and 18 cases at 6 months follow up while 37 and 43 cases had severe irregular bleeding at 3 and 6 months follow up respectively. At baseline, 89 and 10 and 1 cases had their blood sugar <100, 100-120 and >120 respectively, at 3 months follow-up, 94, 6 and 0 cases had their blood sugar level <100, 100-120 and >120 respectively while at 6 months follow-up 97, 3 and 1 cases had their blood sugar level <100, 100-200 and >200 respectively.

Conclusions: Injection DMPA use in postpartum period is safe, effective and reversible method with no deleterious metabolic effects and do not need special training to administer to it, so it is a good option of contraception for women who are lactating.
\end{abstract}

Keywords: Depot medroxy progesterone acetate, Irregular bleeding, Postpartum period

\section{INTRODUCTION}

Population explosion is a major issue especially in our country with the second largest population in world next only to china starting the use of contraception in postpartum period is an effective method of increasing the gap between two pregnancies and hence reducing the family size.

There were 620,472 reported abortions in 2012; experts say the true number of abortions performed in the country could be as high as 7 million, with two-thirds of them taking place outside authorized health facilities. ${ }^{1}$ Therefore, it seems to be a feasible option to increase family planning services at grass root level, it appears to be rational and effective method in temporarily motivated postpartum women specially in low resource settings, where patient training and follow up along with patient education is not optimal. ${ }^{2}$

Since then DMPA has become a popular contraceptive and has been one of the most extensively researched drugs with an accumulated research experience of over 3 million women months of use with more than a thousand 
published scientific papers and reviews. It is now a widely used contraceptive and is approved for use in more than 130 countries. $^{3}$

\section{METHODS}

The present study titled was carried out in the department of obstetrics and gynecology, S. P. Medical College, Bikaner June 2018 to May 2019. Total 100 patients meeting the inclusion criteria were recruited in the study after taking informed written consent.

A preliminary contact was made on the day of delivery. Mothers were explained about all the available methods of contraception. A detailed explanation regarding study procedure was given. Eligibility then determined and after obtaining informed consent women were enrolled. Breast feeding was started $1 / 2-1$ hour after delivery and 23 hourly thereafter. As a result, most of the women had adequate lactation even on $2^{\text {nd }}$ postpartum day. All women were breast feeding at time of discharge and intended to continue breast feeding at home.

A total of 100 women, who opted for hormonal contraception in form of depot medroxy progesterone acetate (DMPA) were recruited as study group. A thorough general physical examination including breast examination of the mother was done. Status of infant's health, weight (by analog scale with standard error of 0.1 $\mathrm{kg}$ ) was recorded. Exclusive breast feeding was emphasized. This comprises frequent suckling on demand and night feeding. All women who chose to use (DMPA) received inj. DMPA $150 \mathrm{mg}$ intra muscularly after 6 weeks of postpartum and then they were followed after 3 months and 6 months. Injection DMPA was given only after confirming establishment of lactation.

\section{Present study was mainly based on following parameters}

- Mother weight

- Hemoglobin

- Blood pressure

- Blood sugar

- Serum bilirubin

- SGOT/PT

- Lipid profile

- Breast feeding

- Bleeding pattern

- Side effects.

\section{Statistical analysis}

To collect required information from eligible patients a pre-structured pre-tested proforma was used. For data analysis Microsoft excel and statistical software SPSS were used and data were analyzed with the help of frequencies, Mean, standard deviation, student ' $t$ ' test, $p$ value of $<0.05$ is considered as significant.

Table 1: Effect of DMPA on bleeding pattern at different follow-up.

\begin{tabular}{|c|c|c|c|c|c|c|}
\hline \multirow{2}{*}{$\begin{array}{l}\text { Irregular } \\
\text { bleeding }\end{array}$} & \multicolumn{2}{|c|}{ At initial visit } & \multicolumn{2}{|c|}{ At 3 months } & \multicolumn{2}{|c|}{ At 6 months } \\
\hline & No. & Percentage & No. & Percentage & No. & Percentage \\
\hline Nil & 71 & 71 & 1 & 1.0 & 1 & 1.0 \\
\hline Mild & 21 & 21.0 & 35 & 35.0 & 38 & 38.0 \\
\hline Moderate & 8 & 8.0 & 27 & 27.0 & 18 & 18.0 \\
\hline Severe & 0 & - & 37 & 37.0 & 43 & 43.0 \\
\hline $\mathrm{p}$ value & $<0.0$ & & & & & \\
\hline
\end{tabular}

\section{RESULTS}

Mild irregular bleeding was present in 21, 35 and 38 cases at initial visit, at 3 months and at 6 months followup respectively. Moderate irregular bleeding was present in 8 cases at initial visit, 27 cases at 3 months and 18 cases at 6 months follow up while 37 and 43 cases had severe irregular bleeding at 3- and 6-month follow-up respectively and this difference was found statistically highly significant $(\mathrm{p}<0.001)$ (Table 1). At baseline, 6 and 94 cases had their haemoglobin 7-8.9 gm/dl and 9-10.9 $\mathrm{gm} / \mathrm{dl}$ while no cases had their haemoglobin $<7$ and $>11$ $\mathrm{gm} / \mathrm{dl}$. At 3 months 13 and 87 cases had their haemoglobin level between 7-8.9 gm/dl and 9-10.9 gm/dl respectively while at 6 month, 33 and 67 cases had their haemoglobin level between 7-8.9 gm/dl and 9-10.9 gm/dl respectively.

Mean haemoglobin at baseline was $9.40 \pm 0.40 \mathrm{gm} / \mathrm{dl}$, at 3 months it was $9.38 \pm 0.52 \mathrm{gm} / \mathrm{dl}$ and at 6 months mean haemoglobin was $9.30 \pm 0.60 \mathrm{gm} / \mathrm{dl}$. On applying student ' $t$ ' test, the difference was found statistically insignificant ( $p>0.05$ ) both baseline versus 3 months and baseline versus 6 months (Table 2). At baseline, 99 and 1 cases had their serum bilirubin level $0.2-1$ and $>1$ respectively while no case had their serum bilirubin $<0.2 \mathrm{mg} \%$. At 3 months follow up, 100 cases had their serum bilirubin level between $0.2-1.2 \mathrm{mg} \%$ while at 6 months follow up 99, 1 case had their serum bilirubin level between 0.2-1.2 $\mathrm{mg} \%$ and $>1.2$ respectively. 
Mean serum bilirubin at baseline was $0.76 \pm 0.09 \mathrm{mg} / \mathrm{dl}$, at 3 months it was $0.75 \pm 0.09$ and at 6 months it was $0.78 \pm 0.09$. On applying student ' $t$ ' test, the difference was found statistically insignificant $(p>0.05)$ both baseline versus 3 months and baseline versus 6 months (Table 3). According to side effect, back pain was present in 5 and 4 cases at 3 and 6 months follow up, headache was present in 5 and 3 cases at 3 months and 6 months follow-up, weight gain was present in 10 and 8 cases at 3, 6 months follow-up respectively, soreness at injection site was present in 7 and 1 cases at 3 and 6 months follow-up respectively while nausea/ vomiting was present in 9 and 2 cases at 3 and 6 months follow-up respectively (Table 4).

Table 2: Effect of DMPA on haemoglobin at different follow-up.

\begin{tabular}{|c|c|c|c|c|c|c|}
\hline \multirow{2}{*}{$\begin{array}{l}\text { Haemoglobin } \\
(\mathrm{gm} / \mathrm{dl})\end{array}$} & \multicolumn{2}{|c|}{ At baseline } & \multicolumn{2}{|c|}{ At 3 months } & \multicolumn{2}{|c|}{ At 6 months } \\
\hline & No. & Percentage & No. & Percentage & No. & Percentage \\
\hline$<7$ & 0 & - & 0 & - & 0 & - \\
\hline $7-8.9$ & 6 & 6.0 & 13 & 13.0 & 33 & 33.0 \\
\hline $9-10.9$ & 94 & 94.0 & 87 & 87.0 & 67 & 67.0 \\
\hline$\geq 11$ & 0 & - & 0 & - & 0 & - \\
\hline Total & 100 & & 100 & & 100 & \\
\hline Mean & 9.40 & & 9.38 & & 9.30 & \\
\hline SD & 0.40 & & 0.52 & & 0.60 & \\
\hline Comparison & & & $\mathrm{t}$ & & $\mathrm{p}$ & \\
\hline Baseline versu & nonths & & 0.030 & & 0.761 & \\
\hline Baseline versu & nonths & & 1.387 & & 0.167 & \\
\hline
\end{tabular}

Table 3: Effect of DMPA on serum bilirubin at different follow-up.

\begin{tabular}{|c|c|c|c|c|c|c|}
\hline \multirow{2}{*}{$\begin{array}{l}\text { Serum } \\
\text { bilirubin mg\% }\end{array}$} & \multicolumn{2}{|c|}{ At baseline } & \multicolumn{2}{|c|}{ At 3 months } & \multicolumn{2}{|c|}{ At 6 months } \\
\hline & No. & Percentage & No. & Percentage & No. & Percentage \\
\hline$<0.2$ & 0 & - & 0 & - & 0 & - \\
\hline $0.2-1.2$ & 99 & 99.0 & 100 & 100.0 & 99 & 99.0 \\
\hline$>1.2$ & 1 & 1.0 & 0 & - & 1 & 1.0 \\
\hline Total & 100 & & 100 & & 100 & \\
\hline Mean & 0.76 & & 0.75 & & 0.78 & \\
\hline SD & 0.09 & & 0.09 & & 0.09 & \\
\hline \multicolumn{3}{|c|}{ Comparison } & $\mathrm{t}$ & & $\mathrm{p}$ & \\
\hline \multicolumn{3}{|c|}{ Baseline versus 3 months } & 0.786 & & 0.433 & \\
\hline \multicolumn{3}{|c|}{ Baseline versus 6 months } & 1.571 & & 0.118 & \\
\hline
\end{tabular}

Table 4: Side effect of DMPA at different follow-up.

\begin{tabular}{|lllll|}
\hline \multirow{2}{*}{ Side effect } & At $\mathbf{3}$ months & & At $\mathbf{6}$ months & \\
\hline Back pain & No. & Percentage & No. & Percentage \\
\hline Headache & 5 & 5.0 & 4 & 4.0 \\
\hline Weight gain & 5 & 5.0 & 3 & 3.0 \\
\hline Soreness at injection site & 10 & 10.0 & 8 & 8.0 \\
\hline Nausea/vomiting & 7 & 7.0 & 1 & 1.0 \\
\hline
\end{tabular}

\section{DISCUSSION}

It was a prospective study conducted between $1^{\text {st }}$ June 2018 to $31^{\text {st }}$ May 2019. The study group comprised of 100 postpartum women delivered at obstetrics and gynecology department in S. P. Medical College Bikaner who wanted some form of reversible contraception after delivery. In this study, irregular uterine bleeding was the main problem, mild irregular bleeding was present in $21 \%, 35 \%$ and $38 \%$ cases at baseline, at 3 months and 6 months follow up respectively. Moderate irregular bleeding was present in $8 \%$ cases at baseline, $27 \%$ cases at 3 months and $18 \%$ cases at 6 moths follow up while $37 \%$ and $43 \%$ cases has severe irregular bleeding at 3 
months and 6 months follow-up respectively and this difference was found statistically highly significant. Fonseca et al, Rani et al, Mishra et al also reported the significant irregular uterine bleeding pattern in their studies which is comparable to this study. ${ }^{4-6}$ Menstrual changes like amenorrhea on irregular bleeding are the most frequent cause for discontinuation of DMPA because this makes women anxious about her menstrual cycle. Therefore, pre-administration counselling is essential to minimize attrition. In this study mean hemoglobin was $9.4 \mathrm{gm} \%$ at the time of treatment start and at follow up of 3 months and 6 months it was 9.38 gm\% and 9.3 gm\% respectively. The difference was found statistically insignificant both baseline versus 3 months and baseline versus 6 months.

In this study mean blood sugar of subject at the time of enrolment was $85.06 \mathrm{mg} / \mathrm{dl}$, at 3 months it was 86.45 $\mathrm{mg} / \mathrm{dl}$ and at 6 months it was $86.13 \mathrm{mg} / \mathrm{dl}$. The difference was found statistically insignificant both baseline versus 3 months and baseline versus 6 months. The study conducted by Rani et al change in blood sugar was not significant which is comparable to this study. ${ }^{5}$ In this study, side effect of DMPA like backache, headache, weight gain, nausea, vomiting, soreness at site of injection also present but these were statistically insignificant. In the study of Fonseca et al, Mishra et al also reported this type of side effect which is comparable to this study. ${ }^{4,6}$

In this study all patients given DMPA did not report a single unintended pregnancy this indicating it higher efficacy and leading ultimately to a high patient satisfaction. Rani et al and Khadilkar et al study also reports no single unintended pregnancy which is comparable to this study. There is a social stigma for the IUCD among the women regarding its complication, inherent risks, especially when it is carried out by less skilled health workers in field rather than hospital setting whereas no special training is required for DMPA injection. Thus, DMPA is a good option of contraception for women who are lactating and want a safe and reversible method of contraception.

\section{CONCLUSION}

Safe contraception is one of the strong pillars of safe motherhood. The unmet need for contraception can be met by promoting use of highly effective, cheap, reversible and easy to administer method. Injection DMPA use in postpartum period is safe, effective and reversible method with no deleterious metabolic effects and do not need special training to administer to it, so it is a good option of contraception for women who are lactating.

Funding: No funding sources

Conflict of interest: None declared

Ethical approval: The study was approved by the Institutional Ethics Committee

\section{REFERENCES}

1. Huang YM, Merkatz R, Kang JZ, Roberts K, Hu $\mathrm{XY}$, Di Donate $\mathrm{F}$, et al. Postpartum unintended pregnancy and contraception practice among rural to urban migrant women in Shanghai. Contracept. 2012;86(6):731-8.

2. Westhoff C. Depot medroxyprogesterone acetate injection Depo Provera: a highly effective contraceptive option with proven long-term safety. Contracept. 2003;68(2):75-87.

3. Malarcher S, Meirik O, Lebetkin E, Shah I, Spieler J, Stanback J. et al. Provision of DMPA by community health workers: what the evidence shows. Contracept. 2011;83(6):495-503.

4. Fonseca M, Deshmukh PY, Kharat D. DMPA: Acceptance and compliance in a tertiary care hospital in Mumbai. Int J Reprod Cntracept Obstet Gynecol. 2017;6(9):3879-81.

5. Rani S. A study on injectable DMPA (Depomedroxy progesterone acetale) isomg use as short-term contraception in immediate postpartum women. Int $\mathbf{J}$ Med Helth Res. 2017;3(9):17-22.

6. Mishra S, Gupta R. Acceptability and compliance of DMPA among rural women in Sitapur UP. Int J Clin Obstet Gynecol. 2019;3(2):8-10.

7. Khadilkar SS. Short term use of injectable contraception: An effective strategy for safe motherhood. J Obstet Gynecol Ind. 2018;68(2):82-7.

Cite this article as: Kochar S, Kumar A, Nama A, Suthar N. A prospective study to know the efficacy of short-term use of injectable depot medroxy progesterone acetate for contraception in tertiary care hospital from North West Rajasthan, India. Int J Reprod Contracept Obstet Gynecol 2020;9:2482-5. 